\section{Evaluating the Cost-effectiveness of Risk-reducing Inputs: Wind Machines for Citrus}

\author{
Steven C. Blank'and \\ Raymond Venner ${ }^{2}$
}

Additional index words. cost-benefit analysis, present value, risk

Summary. This study develops a method of estimating wind machine effectiveness. The method captures the important variables affecting costeffectiveness and can be applied at little cost. The present-value method outlined may be applied when evaluating frost protection for other crops and other risk-reducing inputs, such as irrigation equipment. Oranges in California are presented as a case study. The empirical results presented indicate that wind machines are generally not cost-effective for California orange producers. However, when the nonfinancial benefits of yield risk reduction are included, it is possible that wind machines are cost-effective for some growers.

W ind machines are large fans fastened to towers about $10 \mathrm{~m}$ high. They are used to take advantage of thermol inversions, the condition in which the air above is warmer than the air beneath. Wind machines blow the higher, warmer air down onto the orchard, warming orange trees during cold winter nights. Reducing frost damage is important because damaged oranges either are not harvested or are sold for

${ }^{1}$ Extension economist, Agricultural Economics Department, University of California-Davis.

${ }^{2}$ Research assistan, Agricultural Economics Department, University of California-Davis.

Giannini Foundation paper no. 1116. We appreciate the insights of Richard Snyder (Biometeorologist, Univ. of California-Davis) and Neil O'Connell (Farm Advisor, Tulare County). The cost of publishing this paper was defrayed in part by the payment of page charges. Under postal regulations, this paper therefore must be hereby marked advertisement solely to indicate this fact. juice and neither option is profitable. Wind machines reduce the number of damaged oranges, but the question remains, "Are wind machines costeffective" ?

The decision to invest in a riskreducing input involves comparing its costs and benefits. In the case of wind machines, the purchase cost alone can be more than $\$ 2000 /$ acre, while the benefits depend on the amount of revenue losses from frost damage that are avoided by using the machines. Revenue losses from frost damage are difficult to forecast and vary. by orchard, yet the cost-effectiveness of the investment must be based on such a forecast.

This study develops a method of estimating wind machine effectiveness. The method is sophisticated enough to capture the important variables affecting cost-effectiveness, yet simple enough to be applied at little cost. The method may be applied when evaluating frost protection of other crops and other risk-reducing inputs, such as irrigation equipment. Oranges in California are presented as a case study because oranges are the crop most often protected by wind machines. Eighty-five percent of the citrus in California's San Joaquin valley is protected by wind machines (Hasbargen et al., 1988).

\section{Estimating cost- effectiveness}

Wind machines are cost-effective if their benefits exceed costs. Benefits and costs are spread over many years. During the first few years, new wind machine costs typically exceed benefits, but, once the machine is paid for, benefits may exceed costs. To assess the feasibility of purchasing equipment, some authors have used the internal rate of return method of discounting cash flows (Hasbargen et al., 1988; van Home, 1989 ). However, the preferred method is the present-value analysis of after-tax cash flows (Boehlje and Eidman, 1984; Hinman and Willet, 1985, Lee et al., 1988).

We used the present-value method so that all future values are discounted to their value today and added together to obtain the net present value for costs and benefits. For an analysis of costs for 15 years, the following equation is used:

$\left.\mathrm{P} \mathrm{V}_{\mathrm{C}}=\mathrm{C}_{1} /(1+\mathrm{i})+\mathrm{C}_{2} /(1+\mathrm{i})^{2}+\mathrm{C}_{3} / 1+\mathrm{i}\right)^{3}$

$+\ldots+\mathrm{C}_{15} /(1+\mathrm{i})^{15}-\mathrm{S}_{15} /(1+\mathrm{i})^{15}$

where $\mathrm{PV}_{\mathrm{C}}=$ the present value of costs; $\mathrm{C}_{\mathrm{n}}$ = the after-tax costs in year $\mathrm{n} ; \mathrm{i}=$ the interest rate used in discounting; and $S_{15}=$ the projected salvage value at year 15 . The salvage value is a cash inflow, so it is subtracted from costs.

Wind machine benefits and costs are projected for 15 years in this study. Wind machines sometimes are used for 40 years, but assigning a salvage value at year 15 is equivalent to analyzing the feasibility over its lifetime. With competitive markets, the present value of profits after year 15 is captured in the salvage value at year 15 .

To compare uneven wind machine costs with annual benefits, an equivalent annual annuity (EM) is used. This value represents the average of discounted cash flows per year. The EAA of total costs is the amount that would be paid each year for 15 years to satisfy a loan equaling the amount of the net present value PVC. The EAA is calculated from the series of net present values as follows:

$\mathrm{EAA}=\mathrm{PV}\{\mathrm{i} /[1-(1+\mathrm{i})-15]\}$

Wind machine profits are the benefits minus costs on an after-tax net present value basis. The equivalent annual annuity of benefits minus that of costs gives an annual average profit (or loss).

Profits are estimated for three types of wind machines: diesel, electric, and propane. Electricity costs have risen sharply, so existing electric ma-

Table 1. Wind machine costs.

\begin{tabular}{lrrrccc}
\hline Type & Purchase (\$) & \multicolumn{2}{c}{ Salvage (\$) Energy (\$) } & Labor (\$) & Repairs (\$) & Inflation (\%) \\
\hline Diesel (new) & 19,000 & 7,500 & 713 & 304 & 100 & 7.0 \\
Propane (new) & 15,000 & 7,500 & 1,381 & 185 & 100 & 5.0 \\
Electric (used) & 4,000 & 0 & 2,078 & 135 & 250 & 7.2 \\
\hline
\end{tabular}

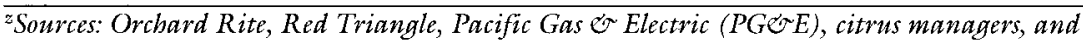
Council of Economic Advisors (1993). Estimates for all machines are $100 \mathrm{~b}$ of operation per year, diesel price of $\$ 0.95 /$ gallon and 6.0 gallons/ $h$, propane $\$ 0.85 /$ gallon and 13.0 gallons/h, maintenance $\$ 75 /$ machine per year, income tax rate of $40 \%$ (combined U.S. and California rates), discount rate $8.0 \%$, and electricity $P G \in E$ rate $A G-4 B W$. 
chines are compared with new diesel and propane machines. Prices and other values are projected for 15 years using 1993-94 levels.

\section{Results: Wind machine costs}

Input prices were obtained from suppliers in the San Joaquin Valley and verified by citrus managers. The current salvage value of existing wind machines is treated as a cost because a grower could sell the machine and receive this value (Table 1 ).

The interest rate used is a grower's cost of borrowing. For commercial orchards, this was $8 \%$ in $1993-94$. The commercial borrowing rate is the cost of capital. Some growers may use a rate higher than the borrowing rate because they add percentage points to serve as a risk premium (an amount charged to cover the costs of risk exposure). Because this premium varies by grower, this study uses the actual cost of borrowing and does not add a risk premium.

Electricity was once the most popular source of power for wind machines, but, in the 1990s, electricity standby (fixed) rates have risen sharply. This has led growers to question the feasibility of continuing to operate existing electric wind machines. Pacific Gas \&Electric (PG\&E) and South ern California Edison (SCE) are the two primary suppliers in California's citrus regions. Sample electricity costs are shown in Table 2 .

Total after-tax costs of wind machines (on an equivalent annual annuity basis) are shown in Table 3. Table 4 presents the analysis for new propane machines, as an example, to illustrate what costs are included.

From the cost results alone it is obvious that San Joaquin Valley growers lose money by continuing to operate electric wind machines supplied by SCE. Existing 100-hp electric and new 125-hp diesel and propane wind machines offer identical frost protection, but the costs are higher for existing SCE electric machines. The estimated costs account for the opportunity to switch to the best alternative, and the best alternative to SCE electric wind machines are new diesel or propane wind machines. Since frost protection is equal among the three types of wind machines, growers maximize profits by choosing the type of wind machine with the lowest annual total costs.

The annual total cost of a 100-hp electric wind machine supplied by SCE is $\$ 60 /$ acre higher than the annual costs of a new diesel or propane wind machine. If wind machines are costeffective, growers could raise profits by $\$ 60 /$ acre by replacing the SCE

Table 2. Wind machine electricity costs for Pacific Gas $\mathcal{O}$ Electric (PGOE) and Southern California Edison (SCE), 1993-94.

\begin{tabular}{|c|c|c|}
\hline$\underline{\text { Standby }}$ & PG\&E & SCE \\
\hline Customer charge ( $\$ /$ month) & $\$ 16.00$ & $\$ 15.20$ \\
\hline Meter charge ( $\$ /$ month $)$ & $\$ 6.00$ & $\$ 0.00$ \\
\hline Sum & $\$ 22.00$ & $\$ 15.20$ \\
\hline No. months & 12 & 12 \\
\hline Total & $\$ 264$ & $\$ 182$ \\
\hline Demand charge $(\$ / \mathrm{kW} /$ month $)$ & $\$ 1.75$ & $\$ 1.25$ \\
\hline $\mathrm{kW} / 100-\mathrm{hp}$ wind machine & 8585 & \\
\hline No. of months demand charge is paid & 6 & 12 \\
\hline Total demand (service) & $\$ 893$ & $\$ 1275$ \\
\hline Total standby & $\$ 1157$ & $\$ 1457$ \\
\hline \multicolumn{3}{|l|}{ Variable } \\
\hline Energy charge $(\$ / \mathrm{kWh})$ & $\$ 0.05964$ & $\$ 0.09896$ \\
\hline $\mathrm{kW} / \mathrm{h}(\mathrm{l} \mathrm{hp}=746 \mathrm{~W})$ & 75 & 75 \\
\hline Hours operated/year & 100 & 100 \\
\hline Total variable costs & $\$ 447$ & $\$ 742$ \\
\hline Total annual cost per wind machine & $\$ 1604$ & $\$ 2200$ \\
\hline
\end{tabular}

"Sources: PGe' E, Dan Goozman. Rates effective 1 July 1993 through 31 Dec. 1994. For PGE E, the variable rate is the night rate $(9: 30 \mathrm{PM}$ to $8: 30 \mathrm{AM}) ; 97 \%$ of the time the wind machines are operating during this time. SCE, Rosemead, Calif. PA-1 schedule effective Winter 1993-94. Schedule PA-1 applies to customers for whom at least $70 \%$ of electricity use is for agricultural purposes. The SCE service charge rate is $\$ 1.75 / \mathrm{hp}$. Wind machine operators typically install a load disconnecting device to prevent use during the summer from 12:00 $P M$ to 6:00 PM and receive a $\$ 0.50$ reduction in the service charge rate. electric machines with new diesel or propane machines. If new machines are not profitable, growers would increase profits by selling the SCE electric machines and not replacing them. Existing electric wind machines with electricity supplied by PG\&E, in contrast, compare favorably with new diesel and propane wind machines.

\section{Results: Wind machine benefits}

Wind machines may offer many benefits, including higher quality, more fresh sales, more production the following year, orange price effects, lower harvesting costs, more certain revenues, and an improved reputation as a reliable supplier of quality citrus. Wind machines improve the quality of fresh citrus by-reducing the brown markings ice makes on peels. Two managers of citrus packing houses estimate that, on average, this improved quality brings growers a $2 \%$ higher price on fresh sales.

The value of the additional quantity of fresh sales equals the product of three variables: price, fresh yield, and increased percentage fresh yield. Prices are on-tree prices-the FOB price minus costs of harvesting and marketing. This is the value of the fruit to a grower and is the economic loss when oranges are frozen. The estimated current ontree price is $\$ 5.00 /$ carton for fresh consumption and $\$ 0$ for juice. The estimated San JoaquinValley fresh yield is 550 cartons/acre for 'Navel' (714 total yield times $77 \%$ fresh) and 475 cartons/acre for 'Valencia' (730 total times $65 \%$ fresh). The projected growth in yields is $1 \%$ /year. Wind machines increase fresh 'Navel' yields by an estimated $6 \%$ and 'Valencia' yields by $7 \%$. These estimates were derived from four sources: 1) a previous study by Hasbargen et al. (1988), which found a $6.75 \%$ increase; 2 ) conversations with citrus managers and farm advisors; 3 ) Federal Crop Insurance Corporation records, which show a difference in loss ratios with and without wind machines differing by $6 \%$; and 4 ) a weather model based on cold-chamber experiments and applied to temperatures across the San Joaquin Valley.

Another potential benefit is higher yields in years following cold periods. During recent interviews, several growers claimed that wind machines protect citrus trees against cold temperatures and lead to higher yields the 
Table 3. Wind machine annual after-tax costs, 1993-94.

\begin{tabular}{lc}
\hline Type $^{2}$ & Cost (\$/acre per year) \\
\hline Diesel, new & 223 \\
Propane, new & 226 \\
Electric, existing (PG\&E) & 231 \\
Electric, existing (SCE) & 286 \\
Diesel, existing & 157 \\
Propane, existing & 187
\end{tabular}

${ }^{\overline{ }}$ Note.. The diesel and propane wind machines are $125 \mathrm{hp}$ and the electric machines are $100 \mathrm{hp}$. Existing machines are currently operated and 20 years old. PGE T. E. Pacific Gas EElectric, SCE. Southern California Edison.

following year. A few growers, however, stated that there is no convincing evidence that wind machines raise subsequent yields. This study estimates that wind machines increase production the following year by an average of $1 \%$.

Previous studies have assigned an orange price effect. This is a value for protecting citrus during cold spells, since citrus prices typically rise during this time. This study, however, assigns no value for this price effect because wind machines help little during the coldest years. Federal Crop Insurance Corporation records show-little different; in loss ratios during the winters with the coldest temperatures-1967 to 1968 and 1990 to 1991.

Another benefit is that wind machines lead to more stable yields. Simulation based on actual yields shows that wind machines reduce variation in citrus yields by $7 \%$. More-stable yields enable citrus managers to be more certain of future fresh yields and en- able them to choose the optimal levels of capital and labor. This improved ability to plan lowers harvesting costs. Citrus on-tree revenues are about $\$ 2500 /$ acre. This study assumes that more-stable yields reduce harvesting costs by $1 \%$ of revenues, or $\$ 25 /$ acre. This is $\$ 0.05 /$ fresh carton $(\$ 25 / 500$ cartons per acre).

A further possible gain is that more-stable yields lead to more-stable revenues (although not perfect, there is a negative correlation, $-\mathrm{O} .6$, between citrus yields and price ). This gain may be valuable to undiversified and highly indebted-growers. As this value may be zero for securely financed firms and may vary widely with the other firms, no value is assigned in this study.

The final benefit listed is the improved reputation as a supplier of quality citrus. Growers can develop a good reputation by delivering relatively few damaged oranges. This improved reputation may enable winning and keep-

Table 4. New propane wind machines (125 hp) annual ownership and operating costs, Winter 1993-94.

\begin{tabular}{|c|c|c|c|c|c|c|c|c|c|c|c|c|c|c|c|}
\hline \multirow[b]{2}{*}{ Cost (\$) } & \multicolumn{15}{|c|}{ Year } \\
\hline & 1 & 2 & 3 & 4 & 5 & 6 & 7 & 8 & 9 & 10 & 11 & 12 & 13 & 14 & 15 \\
\hline \multicolumn{16}{|l|}{ Ownership } \\
\hline \multicolumn{16}{|l|}{ Purchase } \\
\hline and installation & 15,000 & & & & & & & & & & & & & & \\
\hline Down payment & 3,000 & & & & & & & & & & & & & & \\
\hline Unpaid balance & 12,000 & & & & & & & & & & & & & & \\
\hline \multicolumn{16}{|l|}{ Annual loan } \\
\hline $\begin{array}{l}\text { payment } \\
\text { Interest payment }\end{array}$ & $\begin{array}{r}3,005 \\
605\end{array}$ & $\begin{array}{r}3,005 \\
605\end{array}$ & $\begin{array}{r}3,005 \\
605\end{array}$ & $\begin{array}{r}3,005 \\
605\end{array}$ & $\begin{array}{r}3,005 \\
605\end{array}$ & & & & & & & & & & \\
\hline $\begin{array}{l}\text { Interest pavment } \\
\text { Principle payment }\end{array}$ & 2,400 & 2,400 & 2,400 & 2,400 & 2,400 & & & & & & & & & & \\
\hline Property taxes & 160 & 149 & 139 & 129 & 120 & 111 & 104 & 96 & 90 & 83 & 78 & 72 & 67 & 62 & 58 \\
\hline Insurance & 0 & 0 & 0 & 0 & 0 & 0 & 0 & 0 & 0 & 0 & 0 & 0 & 0 & 0 & 0 \\
\hline Management & 30 & 32 & 33 & 35 & 36 & 38 & 40 & 42 & 44 & 47 & 49 & 51 & 54 & 57 & 59 \\
\hline Total & 6,196 & 3,186 & 3,169 & 3,162 & 150 & 144 & 139 & 134 & 126 & 123 & 121 & 119 & 117 & & \\
\hline \multicolumn{16}{|l|}{ Operating } \\
\hline Propane gas & 1,105 & 1,160 & 1,218 & 1,279 & 1,343 & 1,410 & 1,481 & 1,555 & 1,633 & 1,714 & 1,800 & 1,890 & 1,984 & 2,084 & 2,188 \\
\hline Propane tank rental & 80 & 84 & 88 & 93 & 97 & 102 & 107 & 113 & 118 & 124 & 130 & 137 & 144 & 151 & 158 \\
\hline Labor & 185 & 194 & 204 & 214 & 225 & 236 & 248 & 260 & 273 & 287 & 301 & 316 & 332 & 349 & 366 \\
\hline Repairs & 0 & 0 & 100 & 105 & 110 & 116 & 122 & 128 & 134 & 141 & 148 & 155 & 163 & $17 !$ & 180 \\
\hline Maintenance & 75 & 79 & 83 & 87 & 91 & 96 & 101 & 106 & 111 & 116 & 122 & 128 & 135 & 141 & 148 \\
\hline Total & 1,445 & 1,517 & 1,693 & 1,778 & 1,867 & 1,960 & 2,058 & 2,161 & 2,269 & 2,382 & 2,501 & 2,627 & 2,758 & 2,896 & 3,041 \\
\hline Total costs & 7,641 & 4,703 & 4,870 & 4,947 & 5,028 & 2,110 & 2,202 & 2,299 & 2,403 & 2,512 & 2,628 & 2,750 & 2,879 & 3,015 & 3,158 \\
\hline \multicolumn{16}{|c|}{ Deductible expenses } \\
\hline Depreciation & 1,071 & 2,143 & 2,143 & 2,143 & 2,143 & 2,143 & 2,143 & 1,071 & 0 & 0 & 0 & 0 & 0 & 0 & 0 \\
\hline Interest & 605 & 605 & 605 & 605 & 605 & 0 & 0 & 0 & 0 & 0 & 0 & 0 & 0 & 0 & 0 \\
\hline Property taxes & 160 & 149 & 139 & 129 & 120 & 111 & 104 & 96 & 90 & 83 & 78 & 72 & 67 & 62 & 58 \\
\hline Management & 30 & 32 & 33 & 35 & 36 & 38 & 40 & 42 & 44 & 47 & 49 & 51 & 54 & 57 & 59 \\
\hline Operating costs & 1,445 & 1,517 & 1,693 & 1,778 & 1,867 & 1,960 & 2,058 & 2,161 & 2,269 & 2,382 & 2,501 & 2,627 & 2,758 & 2,896 & 3,041 \\
\hline Total & 3,312 & 4,446 & 4,613 & 4,690 & 4,771 & 4,253 & 3,371 & 2,403 & 2,512 & 2,628 & 2,750 & 2,879 & 3,015 & 3,158 & \\
\hline Tax savings & 1,325 & 1,778 & 1,845 & 1,876 & 1,909 & 1,701 & 1,738 & 1,348 & 961 & 1,005 & 1,051 & 1,100 & 1,152 & 1,206 & 1,263 \\
\hline Salvage value & & & & & & & & & & & & & & & 7,500 \\
\hline \multicolumn{15}{|l|}{ Depreciated value } & 0 \\
\hline \multicolumn{15}{|l|}{ Capital gain or loss } & 7,500 \\
\hline \multicolumn{15}{|l|}{ Tax on gain } & 3,000 \\
\hline Total after-tax costs & 6,316 & 2,925 & 3,025 & 3,071 & 3,120 & 409 & 464 & 951 & 1,442 & 1,507 & 1,577 & 1,650 & 1,727 & 1,809 & $-2,605$ \\
\hline \multicolumn{16}{|l|}{$\begin{array}{l}\text { Present value } \\
\text { (after tax; } \$ \text { /acre) }\end{array}$} \\
\hline Net present value & $\begin{array}{r}5,040 \\
19,360\end{array}$ & 2,508 & 2,401 & $2,25 /$ & 2,123 & 258 & 271 & 314 & 721 & 698 & 676 & 655 & 635 & 616 & -821 \\
\hline \multicolumn{16}{|c|}{$\begin{array}{l}\text { Equivalent annual } \\
\text { annuity } \\
\text { 2,262 }\end{array}$} \\
\hline \multicolumn{16}{|l|}{ Acres/wind } \\
\hline \multicolumn{16}{|l|}{ Equivalent annuity } \\
\hline (\$/acre/year) & 226 & & & & & & & & & & & & & & \\
\hline
\end{tabular}


ing more marketing contracts. A $2 \%$ quality premium already has been assigned, so no additional value is assigned for this factor.

These and other possible benefits are difficult to estimate accurately. Also, protection varies by orchard due to unique conditions and winter temperatures. Temperatures vary across the San Joaquin Valley by at least 3F. This is significant, as "wind machines raise orchard temperatures by about $2 \mathrm{~F}$. Within the citrus belt, the colder the temperatures, the greater is the general level of protection and profitability of wind machines (Hasbargen et al.; 1988).

\section{Results: Profitability}

A range of benefits are estimated and compared with costs to obtain the estimated profitability of wind machines for an average San Joaquin Valley citrus orchard. On average, wind machines are not profitable. Profits are lowest for existing electric wind machines (Table 5).

In addition to estimated profit per acre, Table 5 presents break-even values for increased fresh yield, total yield, and price. Holding the other variables at their estimated values, break-even values are calculated by changing the value of the variable until wind machine profits are zero. As an example, new propane wind machines are estimated to be profitable for 'Navel' yields exceeding 690 cartons/acre. New 125 -hp propane wind machines are profitable if they increase fresh yield by $8.1 \%$ for 'Navel' and $9.7 \%$ for 'Valencia'. Citrus growers can estimate the actual frost protection of wind machines for each orchard and compare their estimate with the breakeven values presented here. If the actual frost protection is greater than the break-even value, then the wind machine is profitable.

\section{Probability of wind ma- chine profits}

Although the results presented in Table 5 appear to indicate that wind machines are not cost- effective, on average, there are circumstances in which profits occur. Many of the variables used in the analysis spreadsheet (such as the one in Table 4) vary over time and, in some cases, result in profits. These random variables include yields, market prices, and other factors with significant influence on the out-

Table 5. Wind machine profits, San Joaquin Valley citrus 1993-94 (annual after-tax \$/acre).

\begin{tabular}{|c|c|c|c|c|}
\hline Profit $^{x}$ & $\begin{array}{c}\text { New } \\
\text { diesel } \\
(125 \text { hp) } \\
\end{array}$ & $\begin{array}{c}\text { New } \\
\text { propane } \\
(125 \text { hp) }\end{array}$ & $\begin{array}{c}\text { Used PG\&E } \\
\text { electric } \\
(\mathbf{1 2 5} \mathrm{hp})\end{array}$ & $\begin{array}{c}\text { Used SCE } \\
\text { electric } \\
(100 \mathrm{hp})\end{array}$ \\
\hline \multicolumn{5}{|c|}{ Navel } \\
\hline Benefit (\$/acre) & 178 & 178 & 178 & 178 \\
\hline Cost (\$/acre) & 223 & 226 & 231 & 286 \\
\hline Profit (\$/acre) & 45 & -49 & -53 & -108 \\
\hline \multicolumn{5}{|l|}{ Break-even levels } \\
\hline \multicolumn{5}{|l|}{ Increased fresh } \\
\hline Percent & $8.0 \%$ & $8.1 \%$ & $8.4 \%$ & $10.9 \%$ \\
\hline Cartons/acre & 44 & 45 & 46 & 60 \\
\hline \multicolumn{5}{|l|}{ Fresh yield } \\
\hline Cartons/acre & 685 & 690 & 720 & 890 \\
\hline Price (\$/carton) & 6.20 & 6.30 & 6.50 & 8.00 \\
\hline \multicolumn{5}{|c|}{ Valencia } \\
\hline Benefit ( $\$ /$ acre) & 172 & 172 & 172 & 172 \\
\hline Cost (\$/acre) & 223 & 226 & 231 & 286 \\
\hline Profit (\$/acre) & -51 & -54 & -59 & -114 \\
\hline \multicolumn{5}{|l|}{ Break-even levels } \\
\hline \multicolumn{5}{|l|}{ Increased fresh } \\
\hline Percent & $9.5 \%$ & $9.7 \%$ & $10.0 \%$ & $13.0 \%$ \\
\hline Cartons/acre & 45 & 46 & 47 & 62 \\
\hline \multicolumn{5}{|l|}{ Fresh yield } \\
\hline Cartons/acre & 610 & 620 & 640 & 790 \\
\hline Price (\$/carton) & 6.40 & 6.50 & 6.50 & 8.30 \\
\hline
\end{tabular}

${ }^{2} P G \mathfrak{r} E=$ Pacific Gas é Electric.

${ }^{y} \mathrm{SCE}=$ Southern California Edison

${ }^{x}$ Increased fresh is the increased percentage of fresh yield due to wind machines. Price is on-tree price of citrus destined for fresh consumption (\$/carton; $37.5 \mathrm{lb}$ net). The benefits include a $2 \%$ quality premium.

come of the analysis. Therefore, a simulation model was developed to estimate profits resulting from all realistic combinations of the random variables. In the model, each random variable was allowed to vary around its current average value by amounts determined by its historical behavior. The simulation was run 500 times to calculate the possible outcomes that would indicate the probability that a profit would occur in any particular year. Table 6 presents the simulation results for each type of wind machine.

As expected, machines with the lowest average losses have the highest probability of generating a profit in a particular year. For 'Navel' oranges, used diesel machines are profitable $65 \%$ of the time, while there is less than a $2 \%$ chance that benefits will exceed costs for existing electric machines using SCE power. Table 6 also shows that potential annual losses for electric machines are quite high, ranging over $\$ 500 /$ acre for 'Navel'.

\section{Explaining negative profits}

New wind machines lower expected profits an average of $\$ 50 /$ acre, yet $85 \%$ of San Joaquin Valley citrus is protected by wind machines. Why? Some possible explanations are as follows:

1 ) Growers do not attempt to maximize wealth.

2) Growers attempt to maximize wealth, yet fail due to lack of information. They may overvalue wind machines.

3) This study undervalues wind machines. This is unlikely, all values were verified by citrus industry representatives.

4) The role of risk has not been addressed. Benefits of more certain yields have not been accounted for and, including these benefits, may lead to positive wind machine profits.

The fourth explanation above is the most likely, although the second explanation is certainly reasonable. Wind machines lead to more stable yields. This reduced risk lowers harvesting costs. This efficiency gain was not included as a benefit in the analysis because it varies among growers and is difficult to measure. How is risk measured? Another term for risk is variability, and it may be measured using the coefficient of variation $(\mathrm{cv})$, which is the standard devia- 
tion divided by the mean.

Harvesting costs vary with yield risk because many costs already have been incurred. A producer chooses much of the harvesting capital and labor before the harvest. If cold temperatures then freeze a portion of the harvest, the grower will have overinvested in harvesting capital and labor. Similarly if fewer oranges freeze than expected, a grower will have chosen less than optimal levels of capital and labor. For both cases, yield risk raises harvesting costs.

Simulations based on historical trends find that wind machines lower the $\mathrm{cv}$ of yields by $7 \%$. What is the value of the efficiency gain associated with $7 \%$ more stable yields? San Joaquin Valley fresh citrus yields are about 400 cartons per acre; $\$ 50 /$ acre is equivalent to $\$ 0.125 /$ carton $(\$ 50 / 400$ cartons). Is the value of more certain yields worth $\$ 0.125 /$ carton? If so, then the $\$ 50 /$ acre may be fully justified by the increased efficiency from more stable yields.

Harvesting and marketing costs are about $\$ 4.00 /$ carton of fresh oranges; $\$ 0.125 /$ carton is $<4 \%$ of the harvesting costs. Another view is that reduced yield risk is worth $\$ 50 /$ acre if it lowers harvesting and marketing costs by $4 \%$.

The efficiency gains from morestable yields vary by firm; e.g., firms that hire seasonal pickers may suffer less efficiency loss from frost than firms with more permanent employees. Some permanent employees may be under-used during years of freeze damage.

In addition to efficiency gains, more-stable yields may increase revenues. Many growers forward-contract and may receive a higher price by selling in advance. A grower with wind machines is more certain of yields, may contract a larger share of expected harvest, and may receive a higher price for the additional oranges contracted.

Another benefit of more stable yields is more stable revenues. Although efficiency is vital to all citrus growers, certainty of revenues and cash flow is an important issue to highly indebted and undiversified growers. Predictable cash flows enable managers to identify credit needs and to reduce the chance of loan defaults.

In total, it is possible that the benefits from the reduced risk of producing oranges protected by wind machines are enough to cover the financial losses reported in this study. However, many growers are beginning to question whether this is true under current market conditions. These growers believe that a lack of current information may lead them to overvalue wind machines. Nevertheless, a risk-averse grower's fear of the potential costs of freezes may be a psychological factor motivating him to knowingly accept the losses of wind machines to lower risk exposure and increase peace of mind.

\section{Summary and conclusions}

Risk-reducing inputs are cost-effective only if their financial costs are

Table 6. San Joaquin Valley wind machine annual profits per acre.

\begin{tabular}{|c|c|c|}
\hline $\begin{array}{l}\text { Wind } \\
\text { mach i ne } \\
\text { type }\end{array}$ & $\begin{array}{c}\text { Probability } \\
\text { of positive } \\
\text { profits } \\
(\%)\end{array}$ & $\begin{array}{c}\text { Range of profits } \\
\text { with a } 95 \% \\
\text { probability } \\
\text { (\$) }\end{array}$ \\
\hline \multicolumn{3}{|c|}{ Navel } \\
\hline Diesel, new & 15.6 & -234 to 67 \\
\hline Propane, new & 18.6 & -288 to 75 \\
\hline Electric, PG\&E ${ }^{2}$, used & 7.8 & -537 to 140 \\
\hline Electric, $S C E^{y}$, used & 1.8 & -504 to 45 \\
\hline Diesel, used & 65.0 & -115 to 159 \\
\hline Propane, used & 43.6 & -265 to 138 \\
\hline \multicolumn{3}{|c|}{ Valencia } \\
\hline Diesel, new & 22.8 & -256 to 264 \\
\hline Propane, new & 29.6 & -305 to 316 \\
\hline Electric, PG\&E, used & 34.2 & -308 to 322 \\
\hline Electric, SCE, used & 9.2 & 493 to 93 \\
\hline Diesel, used & 50.6 & -175 to 434 \\
\hline Propane, used & 40.8 & -299 to 304 \\
\hline
\end{tabular}

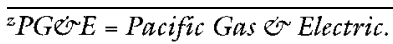

${ }^{y} S C E=$ Southern California Edison.

smaller than their benefits. The benefits of such an input may be financial and nonfinancial. In the case of wind machines for citrus, the financial benefits include the value of production saved. Nonfinancial benefits include such factors as the peace of mind a grower has in knowing that some yield risk has been reduced.

For this case study, a model was developed to estimate the financial costs and benefits of wind machines to California orange growers. Break-even levels for yield, prices, and production saved were estimated also. Growers may compare data from their farm with these break-even values to make a more informed decision regarding purchasing this risk-reducing input.

The net present value method used here may be applied easily to other crops, such as grapes and apples, in addition to other equipment that reduces production loss and risk, such as irrigation pumps and more-efficient harvesting equipment. Cost-effectiveness depends on expected prices and production saved. In each case, a weather model may be developed to define production saved as a function of one or a few weather variables and applied to sites throughout the production region.

The empirical results presented indicate that wind machines are not generally cost-effective for California orange producers. However, when the nonfinancial benefits of yield risk reduction are included, it is possible that wind machines are cost-effective for some growers. The thrust of this paper is that growers should formally evaluate the cost-effectiveness of this type of investment before making it and periodically after it has been made to judge whether the future benefits still justify the costs. If the economic environment changes after an investment is made, like it has for users of electric wind machines in this case study, the best decision may be to liquidate the assets.

\section{Literature Cited}

Blank, S., K. Klonsky, and K. Norris. 1992. Evaluating equipment acquisition alternatives. HortTechnology 2:238-243.

Boehlje, M. and V. Eidman. 1984. Farm management. Wiley, New York. p. 590592.

Brewer, R. 1977. Recent trends in frost 


\section{PRODUCTION AND MARKETING REPORT}

protection methods in California. Proc. Intl. Soc. Citricult. 1:196-199.

Carmen, D. 1991. Critical weather conditions for frost: Frost and freeze weather patterns of the southern San Joaquin Valley. Conf. Frost Protection, Visalia, Calif. California State Univ.-Fresno. p. 27-48.

Council of Economic Advisors. 1993. Economic report of the president. U.S. Govt. Printing Office, Washington, D.C.

Evans, R. 1991. Frost protection techniques for trees in the northwest: The Washington experience. Conf. Frost Protection, Visalia, Calif., California State Univ.-Fresno. p. 111-136.

Hasbargen, P. 1978. Wind machines for frost protection. California State Univ.Fresno.
Hasbargen, P., V. Eidman, and J. Pherson. 1988. Wind machines for frost protection: An economic analysis. California State Univ.-Fresno.

Kasimatis, A., B. Bearden, R. Sisson, and K. Bowers. 1982. Frost protection for north coast Vineyards. Univ. of California Coop. Ext. Lflt. 2743.

Lee, W., M. Boehlje, A. Nelson, and W. Murray. 1988. Agricultural finance. 8th ed. Iowa State Univ. Press, Ames. p. 1131177.

O'Connell, N. and J. Pehrson. 1991. Survey of citrus damage from 1990 freeze. Univ. of California Coop. Ext., Tulare County, and Lindcove Field Station.

O'Connell, N. and J. Pehrson. 1986. Wind machines for frost protection-Tulare
County, 1986. Univ. of California Coop. Ext., Tulare County, and Lindcove Field Station.

Pehrson, J. 1976. Citrus notes. Univ. of California Coop. Ext., Tulare County, January.

Statewide Integrated Pest Management Project. 1994. Impact weather stations, UCIPM computer system. Univ. of California.

Synder, R. 1993. Wind machines for freeze protection. Final Draft Rpt., November.

Takele, E. 1993. California and Arizona oranges. Univ. of California Coop. Ext. Lflt. 2355.

Van Horne, J. 1989. Financial management and policy. 8th ed. Prentice Hall, Englewood Cliffs, N.J. 